\title{
Orta Okul Fen Bilimleri Dersi Sınav Sorularının Bloom’un Bilişsel Alan Taksonomisine Göre Değerlendirilmesi: Muş İli Örneği*
}

\section{The Evaluation of Middle School Science Examination Questions According to Bloom's Cognitive Domain Taxonomy}

\author{
Hasan Güleryüz, ${ }^{\mathrm{a}, * *}$ İbrahim Erdoğan ${ }^{\mathrm{b}}$ \\ aAtatürk Üniversitesi, Eğitim Bilimleri Enstitüsü, 25240, Erzurum/Türkiye \\ ORCID: 0000-0002-0941-4969
}

b Prof. Dr., Muş Alparslan Üniversitesi, Eğitim Fakültesi, Fen Bilgisi Eğitimi Bölümü, 49250, Muş/ Türkiye. ORCID: 0000-0001-5522-9871

\section{MAKALE BILGİSI}

\section{Makale Geçmiși:}

Başvuru tarihi: 17 Kasım 2017

Düzeltme tarihi: 10 Aralık 2017

Kabul tarihi: 12 Aralık 2017

\section{Anahtar Kelimeler:}

Bloom Taksonomisi

Fen Bilimleri

Soru Analizi

\section{ARTICLE INFO}

\section{Article history:}

Received 17 November 2017

Received in revised form 10 December 2017

Accepted 12 December 2017

\section{Keywords:}

Bloom Taxonomy

Question Analysis

Science and Technology

\section{ÖZ}

Araștırmanın amacı, ortaokul 5, 6, 7 ve 8. sınıf Fen Bilimleri dersi sınav sorularının Bloom'un Bilişsel Alan Taksonomisine göre analizini yapıp, soruların nasıl bir dağılım gösterdiğini bulmaya çalışmaktır. Araştırmada nitel araştırma yaklaşımı çerçevesinde doküman inceleme yöntemi kullanılmıştır. Bu amaçla, 2013-2014 eğitim öğretim yılında Muş merkezde bulunan toplam 29 Fen Bilimleri öğretmeninden, Fen Bilimleri dersine ait 4868 adet yazılı sınav sorusu elde edilmiştir. 1. ve 2. döneme ait yazılı sınav sorusu alınmıştır. Bu soruların analizleri uzman görüşleri doğrultusunda yapılmıştır. 29 Fen Bilimleri öğretmeninden 21 öğretmenle mülakat yapılıp çıkan sonuçların sebepleri araștırılmıștır. Bloom'un Bilișsel Alan Taksonomisine göre yapılan analizler neticesinde toplam soruların \%59,5'i bilgi, \%20,4'ü kavrama, \%13,4'ü uygulama, \%5,2'i analiz, \%1,5'i sentez ve \%0'1 değerlendirme düzeyinde olduğu saptanmıştır.

\section{A B S T R A C T}

The purpose of the study is to analyze $5,6,7$ and $8^{\text {th }}$ grade science and technology course exam questions of secondary schools according to Bloom's Taxonomy of the Cognitive Domain and question forms and to try to find out how a distribution the questions have. In the research, document analysis method was used in the framework of the qualitative research approach. For this purpose, 4868 science and technology questions were received from 29 teachers in the center of Muş in 2013 - 2014 education year. First and second term period exam questions obtained from these exam questions were written. Analysis of these questions was conducted in accordance with expert opinion. As a result of the analysis carried out according to Bloom's Cognitive Domain Taxonomy, it was determined that total questions' $59.5 \%$ were information, $20.4 \%$ were understanding, $13.4 \%$ were application, $5.2 \%$ were analysis, $1,5 \%$ were synthesis and $0 \%$ was assessment level.

\section{Giriş}

Yapılandırmacı öğrenme kuramı çerçevesinde, öğretmenlerin görevlerinden birisi belirlenen amaçlar doğrultusunda öğretim programlarında yer alan, istenilen davranışların öğrencilere kazandırılmasıdır. Öğretim süresi içerisinde öngörülen hizmetler arasında yer alan ölçme ve değerlendirme işlemi öğrencilere kazandırılması amaçlanan davranışların nasıl kazandırılacağını belirlemektedir. Eğitim ve öğretim süreci bir amaç ile başlar, bu süreç öğrenme ögretme faaliyetleriyle devam eder ve değerlendirme ile sonuçlanır. Değerlendirme sürecinden önce ölçme işlemi yapılması gerekir (Gündüz, 2010). Ölçme işlemine başlamadan önce, ölçme araçlarının ve bu araçların özellikleri hakkında bilgi sahibi olmak gereklidir.

Öğrencilerin bilişsel yeteneklerini sınıflandırmada kullanılan en önemli ölçüt Bloom tarafından geliştirilen

\footnotetext{
*Bu çalışma, 2016 yılında Muş Alparslan Üniversitesi Fen Bilimleri Enstitüsü tarafından kabul edilen “5., 6., 7., 8. Sinıfların Fen ve Teknoloji Dersine Ait Sinav Sorularının Bloom Taksonomisine Göre Değerlendirilmesi” adlı Yüksek Lisans tezinden türetilmiştir.

** Sorumlu yazar/Corresponding author.

e-posta: guleryuz_hasan@yahoo.com
} 
taksonomidir. BloomTaksonomosi en basit bilişsel öğrenme seviyesinden en derin öğrenme seviyesine, istendik davranışların basitten karmaşığa, kolaydan zora, somuttan soyuta, birbirinin önkoşulu olacak şekilde aşamalı bir şekilde altı basamaktan meydana gelmektedir. Bunlar alt düzey düşünme becerileri (Bilgi, Kavrama, Uygulama) ve üst düzey düşünme becerileri (Analiz, Sentez, Değerlendirme) olarak iki ayrılır (Birgin, 2016).

Bilgi: Bilgi basamağı, en basit şekliyle bilginin hatırlanması ve tanınmasıdır. Yani unutulan bir bilgiyi geri hatırlamaktır. Bilgi basamağı, alt düzey düşünme becerilerin ilk basamağıdır (Akpınar, 2003).

Kavrama: Kavrama basamağı, öğrenilen bilgileri anlama, çevirme, yorulmama veya ortaya çıkan bir problemi kendine ait kelimelerle ifade edebilmesidir.

Uygulama: Uygulama basamağı, öğrencinin verilen herhangi bir bilgiyi eksiksiz bir şekilde hatırlamaları ya da öğrendiği şeyleri kendisine ait cümlelerle belirtmeleri yeterli değildir. Öğrencinin öğrendikleriyle karşılaştığı problemleri çözmesidir. Öğrenilenlerin karşı tarafa bilgiyi nasıl aktardığını ve yeni problemlerin çözümünde nasıl bir yol çizeceğini gösterir (Köğce ve Baki, 2009).

Analiz: Analiz basamağı, bir bütünün parçalarını oluşturan öğelerin bütünü tanımak, bunları birbirinden ayırmak ve aralarındaki ilişkileri bilmektir.

Sentez: Sentez basamağı, öğeleri bir araya getirerek yeni bir ürün meydana getirilmesine denir. Özgünlük ve yaratıcılık olması lazımdır (Baysen, 2006; Dursun, 2014).

Değerlendirme: Değerlendirme basamağına ait sorular tek cevaplı olmayıp, öğrencinin kendi fikirlerini kullanarak herhangi bir konu hakkındaki problem ve amaca bulunan cevap, metot, işlem ya da ürün hakkında kendi fikirlerini söylemesi, bu fikirlerinin arkasında durması ve bu fikirlerini savunmas1 gerekmektedir (Kaptan, 1998).

Öğretim programının başarısının belirlenmesi ölçme değerlendirme sayesinde olmaktadır. Programda öğrencilerin başarısını ölçmek ve eksiklerini tespit etmek ancak doğru bir ölçme değerlendirme sistemiyle mümkün olmaktadır. $\mathrm{Bu}$ nedenle ölçme ve değerlendirme basamağının doğru bir şekilde planlanıp, doğru uygulanmasına ve çıkan sonuçların doğru değerlendirilmesine ihtiyaç vardır (Guleryuz, 2016). Yapılandırmacı eğitim sistemimizde asıl hedef, öğrencilerimize var olan bilgileri aktarmaktan çok bilgiye ulaşma becerilerini kazandırmak olmalıdır. $\mathrm{Bu}$ ise üst düzey düşünme süreç becerileri sayesinde mümkün olur. Asıl amaç, ezberden çok, kavrayarak öğrenme, karşılaşılan yeni durumlarla ilgili problemleri çözebilme ve bilimsel yöntem süreciyle ilgili becerileri gerektirir (Yaşar, 1998).

\subsection{Araştırma Problemleri ve Alt Problemler}

\subsubsection{5., 6., 7. ve 8. Sinif Fen Bilimleri derslerine ait sinav sorularının Bloom'un Bilişsel Alan Taksonomisine göre analizi nasıl bir dağılım göstermektedir?}

(i) 5. sınıf Fen Bilimleri öğretmenlerinin Fen Bilimleri derslerine ait sınav sorularının Bloom'un Bilişsel
Alan Taksonomisine göre analizi nasıl bir dağılım göstermektedir?

(ii) 6. sınıf Fen Bilimleri öğretmenlerinin Fen Bilimleri derslerine ait sınav sorularının Bloom’un Bilişsel Alan Taksonomisine göre analizi nasıl bir dağılım göstermektedir?

(iii) 7. sınıf Fen Bilimleri öğretmenlerinin Fen Bilimleri derslerine ait sınav sorularının Bloom'un Bilişsel Alan Taksonomisine göre analizi nasıl bir dağılım göstermektedir?

(iv) 8. sınıf Fen Bilimleri öğretmenlerinin Fen Bilimleri derslerine ait sınav sorularının Bloom'un Bilişsel Alan Taksonomisine göre analizi nasıl bir dağılım göstermektedir?

1.1.2. Mülakat Sorulart: 5., 6., 7. ve 8. sinif Fen ögretmenlerinin Fen Bilimleri derslerine ait yazll sınav soruları ile ilgili görüsleri nedir?

(i) Öğrencilerinizin hangi bilişsel seviyede düşünme becerilerine sahip olmasını istersiniz?

(ii) Öğrencilerinizin üst düzey düşünme becerileri gerektiren soruları çözebilme kapasitesine sahip olduğunu düşünüyor musunuz? Bu yönde onları destekleyici çalışmanız var mı?

(iii) Yazılı sorularının çoğunun alt düzey düşünme becerileri gerektiren sorular olmasının sebebi nedir?

(iv) Yazılı sınavlarda neden üst düzey düşünme becerileri gerektiren (analiz, sentez ve değerlendirme) sorular fazla sorulmuyor?

(v) Yazılı sınavlarda üst düzey düşünme becerileri gerektiren sorular sorulduğunda sizce öğrenciler bu soruları çözebilirler mi?

\subsection{Araştırmanın Önemi ve Amacı}

Yapılandırmacı eğitimde öğretmenin görevi, öğrencilerin bilgiyi keşfetmelerini sağlayıp öğrencilerin, üst düzey düşünme becerileri olan analiz, sentez ve değerlendirme yapmalarını sağlamaktır. Öğrencilerin sonraki eğitim ve öğretim hayatlarında daha meraklı, eleştirel, yaratıcı, özgüven sahibi ve çok yönlü özelliklere sahip şahıslar olmalarına katkı sağlayacaktır.

Fen Bilimleri dersine ait yazılı sınav sorularının Bloom'un Bilişsel Alan Taksonomisine göre analizi ile alakalı geçmiş araştırmaların hemen hepsinde tek bir sınıf düzeyinde veya konu bazında anlık durum saptamaları yapılmıştır. $\mathrm{Bu}$ sonuçlar önemli olmasına rağmen, yeni uygulanmaya konulan Fen Bilimleri öğretim programının sınav sorularına etkilerini daha iyi yorumlamak için farklı sınıf düzeylerinde incelemeye ihtiyaç vardır.

\section{Yöntem}

\subsection{Yöntem ve Sinırlamalar}

Bu çalışmada nitel araştırma yönteminden, doküman analizi metodu kullanıldı. Örneklem grubu olarak Muş ili merkez ortaokullar ele alınmış olup, bu kurumlarda çalışan 29 Fen Bilimleri öğretmeninin 2013-2014 Eğitim ve Öğretim yılı Fen Bilimleri derslerine ait 4868 adet yazılı sınav sorusu bir yıl boyunca toplanmıştır. Toplanan bu yazılı sınav soruları Bloom'un Bilişsel Alan Taksonomisine göre analizleri 
yapılmıştır. Ayrıca çıkan sonuçlara göre 21 Fen Bilimleri öğretmenlerine mülakat yapılıp çıkan sonuçların sebepleri araştırılmıştır.

\subsection{Evren-Örneklem}

Çalışmanın örneklemini Muş ili merkez muhtelif ortaokullarda bulunan 29 Fen Bilimleri öğretmenleri oluşturmaktadır. Ortaokul 5, 6, 7 ve 8. sınıf Fen Bilimleri derslerine giren öğretmenlerin yazılı sınavlarında sordukları 4868 adet Fen Bilimleri yazılı sorularından 5. sınıf 32 yazılı sinavdan 1384 soru, 6. sinıf 39 yazılı sinavdan 1682 soru, 7. sinif 23 yazilı sinavdan 995 soru, 8.sinif 27 yazılı sinavdan 807 sorusu yazılı sınav soruları bir yıl boyunca toplanmıştır.

\subsection{Verilerin Analizi}

Örneklem grubu olarak alınan, okullardan elde edilen 4868 adet Fen Bilimleri derslerinin yazılı sinav soruları, bir öğretim üyesi ve bir uzman (doktora öğrencisi ) ve iki Fen Bilimleri dersi öğretmeni eşliğinde incelenmiştir. Araştırmacı tarafindan sorular Bloom'un Bilişsel Alan Taksonomisine göre Çizelge 3.1., Çizelge 3.2., Çizelge 3.3., Çizelge 3.4. dikkate alınarak sınıflandırılmış ve bunların frekans ve yüzdeleri hesaplanmıştır. Aynı veriler bir uzman tarafından tasnifleri yapılmıştır. Sonra uzman ve araştırmacı bir araya gelmiş ve ortaya çıkan sonuçları karşılaştırmışlardır. Uyuşmazlıklar gözden geçirilmiş uzlaşılmayan sorular veri tabanından çıkarılmıştır. Uzlaşı olana kadar bu süreç iki defa daha tekrar edilmiş ve en sonunda uyuşma oranı \% 80 üzeri olunca araştırmacının kendi başına kalan soruları tasnif edebileceği kanaati oluşmuştur. Araştırmacı tarafından tüm soruların tasnifi yapıldıktan sonra yine rastgele belli oranda sorular uzman tarafında incelenmiş ve uyuşmanın \% 95 üzeri olduğu gözlenmiştir. Araştırmacının kararsız kaldığı sorular tekrar uzman eşliğinde gözden geçirtilmiş uzlaşılmayan sorular çıkarılmıştır (Guleryuz, 2016). Böylece, Fen Bilimleri dersleri için hazırlanmış yazılı sınav soruları Bloom'un Bilişsel Alan Taksonomisine göre analizleri yapılmış ve ortaya çıkan sonuçlar yorumlanmıştır. Elde edilen bu verilerden çeşitli varsayımlarda bulunularak, Fen Bilimleri yazılı sorularının Bloom'un Bilişsel Alan Taksonomisine göre, yazılı soruların hangi düzeylerde hazırlandığı hakkında bir kanaat meydana getirmeye çalışılmıştır.

\section{Bulgular}

Burada, 5., 6., 7. ve 8. sinıf Fen Bilimleri dersinde sorulan yazılı soruların Bloom'un Bilişsel Alan Taksonomisine göre analiz yapılmış ve çıkan sonuçlarına göre, her bir kategoriye ait soru sayıları ve yüzdeleri çizelgeler halinde gösterilmiştir. Gerekli olan bilgilerde grafiklerde verilmiştir. Çıkan sonuçların nedenini araştırmak için öğretmenlerle mülakat yapılmış ve bu mülakat sorulara verilen cevaplara göre oran ve yüzdelikleri bulunmuştur.

\subsection{Fen Bilimleri Dersine Ait Yazılı Sinav Sorularının Bilişsel Alan Düzeyleri ve Soru Örnekleri}

Burada, 5, 6, 7 ve 8. sinif Fen Bilimleri derslerinde sorulan yazılı sınav soruların Bloom'un Bilişsel Alan Taksonomisine göre analizleri literatürdeki veriler dikkate alınarak sınıflandırılmıştır.

Tablo 1. 5., 6.,7. ve 8. Sınıf Fen Bilimleri Derslerine Ait Soru Örnekleri ve Bilişsel Alan Düzeyleri

\begin{tabular}{|c|c|}
\hline Bilişsel Alan Düzeyi & 5. Sinıf Fen Bilimleri Dersine Ait Örnek Sorular \\
\hline Bilgi & Dünyamızı ve ayı aydınlatan 1sı ve 1şık kaynağı nedir? \\
\hline Kavrama & Çiçekli ve çiçeksiz bitkilerin arasındaki farkları yazınız? \\
\hline Uygulama & Çiçekli bitki figüründe çiçeğin kısımlarını gösteriniz? \\
\hline Analiz & Dünya, Güneşin etrafinda dönmeseydi ne gibi sonuçlar ortaya çıkardı? \\
\hline Sentez & Karada yaşayan yeşil bitkiler olmasaydı Dünyanın $\mathrm{O} 2$ üretimini hangi canlılar sağlardı? \\
\hline Değerlendirme & Ülkemizde doğal afetlere karşı yapılan hazırlıklar yeterli buluyor musunuz? Niçin? \\
\hline Bilişsel Alan Düzeyi & 6. Sinıf Fen Bilimleri Dersine Ait Soru Örnekleri \\
\hline Bilgi & Kana kırmızı rengini veren madde nedir? \\
\hline Kavrama & Çizgili kas ile düz kas arasındaki farkları yazınız? \\
\hline Uygulama & Hayvan hücresi modelinde organelleri gösteriniz? \\
\hline Analiz & Küçük kan dolaşımı olmasaydı. Vücudumuzda ne gibi olumsuz sonuçların olacağını açılayınız? \\
\hline Sentez & Destek ve hareket sisteminin sağlığını korumak için ne önerirsiniz? \\
\hline Değerlendirme & Erginlik dönemindeki değişiklikler bazı gençleri olumsuz etkiler çözümü için en uygun metot hangisidir? Niçin? \\
\hline Bilişsel Alan Düzeyi & 7. Sınıf Fen Bilimleri Dersine Ait Soru Örnekleri \\
\hline Bilgi & Sodyum elementinin sembolü nasıl yazılır? \\
\hline Kavrama & İyonik bağ ile kovalent bağ arasındaki farklar nelerdir? \\
\hline Uygulama & Kulak modelinde kulağın bölümlerini gösteriniz? \\
\hline Analiz & $\mathrm{CaOH}_{2} \mathrm{Ca}^{+2}+\mathrm{OH}^{-}$ \\
\hline Sentez & Atom yapısının, element, bileşik ve bağların kavram haritasını çiziniz? \\
\hline Değerlendirme & Omurilik soğanı zedelenen bir insan niçin istemsiz davranışlar en çok etkilenir? \\
\hline Bilişsel Alan Düzeyi & 8. Sınıf Fen Bilimleri Dersine Ait Soru Örnekleri \\
\hline Bilgi & Turnusol kağıdın rengini mavi renge çeviren nedir? \\
\hline Kavrama & Asit ve bazların özellikleri arasındaki farklar nelerdir? \\
\hline Uygulama & Besin piramidi şeklini çizerek basamakların adlarını yazınız? \\
\hline Analiz & Hemofili taşıııcı bir anne ile hemofili hasta olmayan bir babanın genlerinin çaprazlayınız. Çıkan sonucu belirtiniz? \\
\hline Sentez & $\mathrm{Mg}(\mathrm{OH})_{2}+\mathrm{H}_{3} \mathrm{PO}_{4} \mathrm{Mg} 3(\mathrm{PO} 4)_{2}+\mathrm{XH}_{2} \mathrm{O}$ \\
\hline Değerlendirme & Yerçekimi kuvveti niçin önemlidir? Açıklayınız? \\
\hline
\end{tabular}


Tablo 2. 5., 6., 7., 8.Sınıfların Fen Bilimleri Dersi Sınav Sorularının Bloom’ un Bilişsel Alan Taksonomisine Göre Soru Adetleri Bazında Dağılımı

\begin{tabular}{lcccccc}
\hline & Bilgi & Kavrama & Uygulama & Analiz & Sentez & Değerlendirme \\
\hline 5. Sinıf & 1217 & 137 & 30 & 0 & 0 & 0 \\
6. Sinıf & 1059 & 373 & 218 & 32 & 0 & 0 \\
7. Sinıf & 378 & 250 & 229 & 129 & 9 & 0 \\
8. Sinıf & 247 & 232 & 176 & 88 & 64 & 0 \\
Toplam & 2901 & 992 & 653 & 249 & 73 & 0 \\
\hline$\%$ & 59,5 & 20,4 & 13,4 & 5,2 & 1,5 & 0 \\
\hline
\end{tabular}

Tablo 3. 5., 6., 7., 8.Sınıfların Fen Bilimleri Dersi Sınav Sorularının Bloom’ un Bilişsel Alan Taksonomisine Göre Yüzdelikleri Bazında Dağılımı

\begin{tabular}{lccccccc}
\hline & Soru Adedi & Bilgi & Kavrama & Uygulama & Analiz & Sentez & Değerlendirme \\
\hline 5.Sinif & 1384 & $\% 88$ & $\% 9,90$ & $\% 2,10$ & $\% 0$ & $\% 0$ & $\% 0$ \\
6.Sinif & 1682 & $\% 63$ & $\% 22,20$ & $\% 13$ & $\% 1,80$ & $\% 0$ & $\% 0$ \\
7.Sinif & 995 & $\% 38$ & $\% 25,20$ & $\% 23,10$ & $\% 13$ & $\% 0,70$ & $\% 0$ \\
8.Sinif & 807 & $\% 30,70$ & $\% 28,80$ & $\% 21,90$ & $\% 11$ & $\% 7,60$ & $\% 0$ \\
\hline
\end{tabular}

5, 6, 7 ve 8. sınıf Fen Bilimleri dersi sınav sorularının Bloom'un Bilişsel Alan Taksonomisine göre hangi düzeyde hazırlandığının belirlenmesinde yukarıdaki Tablo 1'den yararlanılmıştır.

3.2. Fen Bilimleri Dersi Sinav Sorularının Bloom'un Bilişsel Alan Taksonomisine Göre Soru Adetleri Bazında Dağılımı ve Grafiğgi

Tablo 2 incelendiğinde, Fen Bilimleri dersi sınav sorularının Bloom'un Bilişsel Alan Taksonomisine göre soru sayılar görülmektedir. Buna göre soruların \%59,5'i bilgi, \%20,4'ü kavrama, \%13,4'ü uygulama, \%5,2'si analiz, \%1,5'i sentez ve $\% 0$ '1 değerlendirme basamağından hazırlandığı görülmüştür. Sonuçlarda görüldüğü gibi, soruların büyük çoğunluğunun alt düzey düşünme becerisi bilgi düzeyinde sorulduğu ve üst düzey düşünme becerisi olan değerlendirme basamağında hiç soru sorulmadığı görülmüştür. Soruların $\% 93,38$ 'i alt düzey; \%6,63'ü da üst düzey düşünme becerilerini sahip olduğu görülmektedir.

Tablo 3 İncelendiğinde, Fen Bilimleri dersi sınav sorularının Bloom'un Bilişsel Alan Taksonomisine göre her sınıfa ait toplam soru sayıları ve yüzdelikleri görülmektedir. Sonuçlarda görüldüğü gibi, soruların büyük çoğunluğunun yüzdelik olarak bilgi basamağından, değerlendirme basamağından hiç soru sorulmadığı görülmüştür.

Şekil 1. 5., 6., 7., 8.Sınıfların Fen Bilimleri Dersi Sınav Sorularının Bloom' un Bilişsel Alan Taksonomisine Göre Dağılım Grafiği

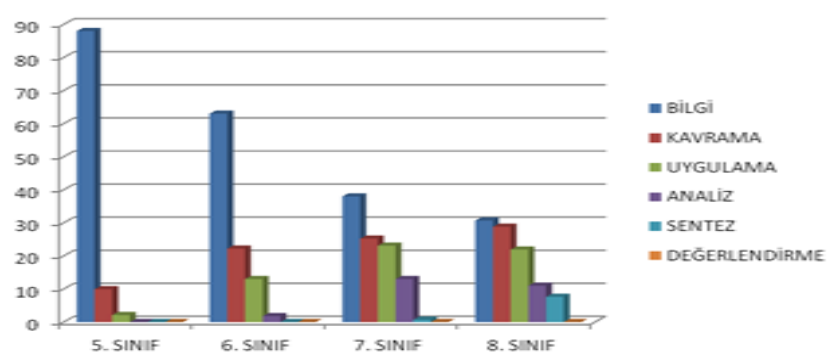

Şekil 1'teki grafikte görüldüğü gibi sınıf seviyelerinin artışına paralel olarak üst düzey düşünme becerileri gerektiren soru sayılarında artış gözlenmektedir. Bilişsel seviyesi üst düzey soru çeşitleri öğrencilerin zamanla çözüm üretmeye, çok yönlü düşünmeye ve yorum yapmaya sevk etmektedir.

\section{3. Öğretmenlerle Yapılan Mülakat Soruları ve Analizi}

2013-2014 Eğitim ve Öğretim y1lı Muş ili merkez ortaokullar ele alınmış olup, bu okullarda görev yapan 29 Fen Bilimleri öğretmeninden 21 öğretmenle mülakat yapılmıştır. Öğretmenlere aşağıda belirtilen yapılandırılmış mülakat soruları sorulmuştur:

(i) Öğrencilerinizin hangi bilişsel seviyede düşünme becerilerine sahip olmasını istersiniz?

(ii) Öğrencilerinizin üst düzey düşünme becerileri gerektiren soruları çözebilme kapasitesine sahip olduğunu düşünüyor musunuz? $\mathrm{Bu}$ yönde onları destekleyici çalışmanız var mı?

(iii) Yazılı sorularının çoğunun alt düzey düşünme becerileri gerektiren sorular olmasının sebebi nedir?

(iv) Yazılı sınavlarda neden üst düzey düşünme becerileri gerektiren (analiz, sentez ve değerlendirme) sorular fazla sorulmuyor?

(v) Yazılı sınavlarda üst düzey düşünme becerileri gerektiren sorular sorulduğunda sizce öğrenciler bu soruları çözebilirler mi?

Öğretmenlerle yapılan mülakat sorularının neticeleri her soru bazında verilen cevapların frekans ve yüzdeleri aşağıda belirtilmiştir.

Tablo 4. Öğrencilerinizin hangi bilişsel seviyede düşünme becerilerine sahip olmasını istersiniz?

\begin{tabular}{lcc}
\hline & $\mathrm{f}$ & $\%$ \\
\hline Sentez seviyesi & 10 & 47.7 \\
Analiz seviyesi & 8 & 38.1 \\
Uygulama seviyesi & 3 & 14.2 \\
Toplam & 21 & 100 \\
\hline
\end{tabular}

Tablo 4 incelendiğinde öğrencilerinizin hangi bilişsel seviyede düşünme becerilerine sahip olmasını istersiniz sorusuna öğretmenlerin $\% 47$ 'si sentez, $\% 38,1$ 'i analiz ve $\% 14,2$ 'si ise uygulama seviyesinde olması gerektiğini vurgulamışlardır. Her ne kadar öğretmenler öğrencilerinin yüksek seviyeli düşünme becerilerine sahip olmalarını istemelerine rağmen, yapılan araştırmada öğretmenlerin yazılı sınavlarda sordukları soruların \%93,38'i alt düzey; $\% 6,63$ 'ü da üst düzey düşünme becerilerini gerektiren sorular olduğu saptanmıştır. 
Tablo5. Öğrencilerinizin üst düzey düşünme becerileri gerektiren soruları çözebilme kapasitesine sahip olduğunu düşünüyor musunuz? Bu yönde onları destekleyici çalışmanız var mı?

\begin{tabular}{lcc}
\hline & $\mathrm{f}$ & $(\%)$ \\
\hline $\begin{array}{l}\text { Destekleyici proje ve performans ödevlerin verilmesi, Laboratuvarda deneylerin yapılması ve zekâ soruların } \\
\text { sorulması }\end{array}$ & 39 & 37.4 \\
\hline Öğrenci kapasitesinin yetersiz olması & 18 & 30 \\
\hline İdeal sınıf ortamının yetersizliği & 8 & 12.5 \\
\hline İleri seviyede düşünme becerileri gerektiren soruları çözen öğrencilerin olması & 7 & 10.9 \\
\hline Sınıfların kalabalık olması & 4 & 6.2 \\
\hline Destekleyici çalışmanın olmaması & 4 & 6.2 \\
\hline Toplam & 64 & 100 \\
\hline
\end{tabular}

Tablo 6. Yazılı sorularının çoğunun alt düzey düşünme becerileri gerektiren sorular olmasının sebebi nedir?

\begin{tabular}{|c|c|c|}
\hline & $\mathrm{f}$ & $(\%)$ \\
\hline Hazır bulunuşluk düzeylerinin düşük olması & 14 & 22.6 \\
\hline Soruların cevaplama oranını yükseltilmesi & 9 & 14.4 \\
\hline Müfredatta yüksek seviyeli soruların çözümü için gerekli düzenlemelerin eksik olması & 9 & 14.4 \\
\hline Yazıları değerlendirmenin kolay olması & 8 & 12.8 \\
\hline Ezberci bir eğitim sisteminden kaynaklanması & 6 & 9.6 \\
\hline Kazanımların bilgi basamağına yönelik olması & 8 & 6.4 \\
\hline Puanlama objektifliğinin en iyi sağlandığı seviye olması & 3 & 4.8 \\
\hline Öğrencinin okul dışında ekstra ders çalışmaması & 3 & 4.8 \\
\hline Yazılı soruları üst düzey becerileri değerlendirmek için uygun bir öğretim aracı olmamas1 & 2 & 3.2 \\
\hline Toplam & 62 & 100 \\
\hline
\end{tabular}

Tablo 7. Yazılı sınavlarda neden üst düzey düşünme becerileri gerektiren (analiz, sentez ve değerlendirme) sorular fazla sorulmuyor?

\begin{tabular}{|c|c|c|}
\hline & $\mathrm{f}$ & $(\%)$ \\
\hline Yüksek seviyeli soruların cevapsız kalma kaygısının olması & 11 & 26.9 \\
\hline İdeal sınıf ortamı yetersiz olmas1 & 8 & 19.5 \\
\hline Öğrenci kapasitesinin yetersiz olması & 7 & 17 \\
\hline Ders sayısının kisitlı olması & 7 & 17 \\
\hline Müfredat1 yetiştirme kaygısının olması & 6 & 14.6 \\
\hline Öğrencinin alternatif bilgilerle desteklenmemesi & 2 & 4.9 \\
\hline Toplam & 41 & 100 \\
\hline
\end{tabular}

Tablo 8. Yazılı sınavlarda üst düzey düşünme becerileri gerektiren sorular sorulduğunda sizce öğrenciler bu soruları çözebilirler mi?

\begin{tabular}{|c|c|c|}
\hline & $\mathrm{f}$ & $(\%)$ \\
\hline Öğrenci kapasitesinin yetersiz olması & 20 & 44.5 \\
\hline Yüksek seviyeli sorular sorulduğunda 3-5 öğrenci çözebilmesi & 8 & 17.8 \\
\hline Öğrencinin soruyu çözemeyip öz güven eksikliğinin yaşanmaması & 8 & 17.8 \\
\hline Müfredatın dışına çıkamama kaygısının olması & 5 & 11.1 \\
\hline Öğrencinin öğrenme isteğinin eksik olması & 4 & 8.9 \\
\hline Toplam & 45 & 100 \\
\hline
\end{tabular}

Tablo 5 incelendiğinde Öğrencilerinizin ileri seviyede düşünme becerileri gerektiren soruları çözebilme kapasitesine sahip olduğunu düşünüyor musunuz? Bu yönde onları destekleyici çalışmanız var mı? Sorusuna \%30 oranla öğrenci kapasitesinin yetersiz olduğunu düşünülmektedirler ve $\% 37,4$ oranla da yetersiz olan öğrenci kapasitelerine destekleyici proje ve performans ödevlerin verilmesi, laboratuarda deneylerin yapılması ve zeka soruların sorulması gibi alternatiflerle öğrencilerin desteklenmesi gerektiğini belirtmektedirler. Öğretmen arkadaşlarımız 1. mülakat sorularında öğrencilerin üst düzey düşünme becerilerine sahip olmalarını istemelerine rağmen öğretmenlerin öğrencilerin bu yeterliliğe sahip olmadıklarını yönünde bir algıya sahip oldukları görülmektedir.

Tablo 6 incelendiğinde Yazılı sorularının çoğunun alt düzey düşünme becerileri gerektiren sorular olmasının sebebi nedir? Sorusuna en yüksek \%22,6 oranla hazır bulunuşluk düzeylerinin düşük olması ve en düşük oranla \%3,2 Yazılı soruları üst düzey becerileri değerlendirmek için uygun bir öğretim aracı olmaması şeklinde görülmektedir.

Tablo 7 incelendiğinde Yazılı sinavlarda neden üst düzey düşünme becerileri gerektiren (analiz, sentez ve değerlendirme) sorular fazla sorulmuyor? Sorusuna en yüksek \% 26,9 Yüksek seviyeli soruların cevapsız kalma kaygısının olması, \%19,5 oranla İdeal sınıf ortamı yetersiz olması, en düşük oranla \%4,9 oranla Öğrenci, alternatif bilgilerle desteklenmemesi şeklinde görülmektedir.

Tablo 8 incelendiğinde Yazılı sınavlarda üst düzey düşünme becerileri gerektiren sorular sorulduğunda sizce öğrenciler bu soruları çözebilirler mi? Sorusuna en yüksek \%44,5 oranla Öğrenci kapasitesinin yetersiz olması, en düşük oranla \%8,9 oranla Öğrencinin öğrenme isteğinin eksik olması şeklinde görülmektedir. 


\section{Tartışma}

Bu çalışmada Bloom'un Bilişsel Alan Taksonomisine göre yapılan analizler neticesinde Fen Bilimleri öğretmenlerinin sinavlarında sordukları toplam soruların $\% 59,5$ 'i bilgi, \%20,4'ü kavrama, \%13,4'ü uygulama, \%5,2'i analiz, \%1,5'i sentez ve \%0'1 değerlendirme düzeyinde olduğu saptanmıştır. Yani alt düzey düşünme becerileri \% 93.3, üst düzey düşünme becerileri \%6,7 olarak görülmektedir. Bu sonuçlar sınıflarımızın hedeflenen programdan çok uzak olduğunu göstermektedir. Ayrıca, elde edilen bulgular Koray vd., (2002), Dindar vd., (2006), Gündüz (2009), Nagihan vd., (2011)tarafından yapılan araştırma sonuçlarıyla paralellik göstermektedir. Koray vd, (2002) yapmış olduğu çalışmada ise soruların \%31,77'sini bilgi, \%44,40'ünü kavrama, \%20'sini uygulama, \%3,40'1nı analiz ve \%0,43'ünün sentez seviyesinde sorulardan oluştuğu ve alt düzey düşünme becerileri \%96.17, üst düzey düşünme becerileri $\% 3.83$ olarak tespit edilmiştir. Aradan geçen yaklaşık 12 yıla ve yenilenen programlar, müfredatlar (2004 ve 2013 Müfredat değişikliğine) kitaplara ve tüm iyileştirme çalışmalarına rağmen fazla bir değişiklik gözlenmemiştir. Alt düzey düşünme becerilerine ait soru hazırlanın, zahmetsiz ve basit olması, değerlendirmenin kolay olması vb. sebepler, bu yöndeki soru sayılarının artmasında belirleyici olduğu ögretmenlerle yapılan mülakat görüşmelerinden anlaşılmaktadır.

Sınavlar, genellikle öğrencilerin işlenen üniteler bağlamında hedeflenen kazanımlara ne derece ulaştıklarını belirlemek amacıyla yapılmaktadır. Yukarıdaki bulgulardan hareketle, Fen Bilimleri öğretmenlerinin Fen Bilimleri derslerinde, en fazla alt düzey düşünme becerileri gerektiren bilgi basamağında soru sordukları bunun yanında üst düzey düşünme becerileri gerektiren değerlendirme basamağından hiç soru sormadıkları görülmektedir. Öğretmenlerin bilgi ağırlıklı ders işlemeleri bunun bir neticesi olabilir. Elde edilen veriler maalesef şunu göstermektedir ki öğretmenler öğrencileri yüksek seviyede düşünceye sevk eden sınıf ortamları oluşturamamaktadırlar ve derslerinde bilgi ağırlıklı ders işlemektedirler.

Alt düzey düşünme becerileri gerektiren soruların fazla kullanılmasının sebeplerinden bir tanesini öğretmenler daha fazla soru ile öğrenciyi test etme ve soru çeşitliliğini artırma olarak vurgulamaktadırlar. Bunun neticesi olarak da öğretmenler yazılı sınavlarda kısa zamanda öğrencilerden cevap alabilecekleri ortalama 20-50 adet yazılı sorusu sormaktadirlar.

Sorular:

A Öğretmen : "Sinavların okumast ve yanıtlaması kolay..." B Öğretmen : “Bazı öğrencilerin yazma becerileri yok
ve yazıları okunaklı değil...”

C Öğretmen : “Değerlendirme süresi çok zaman allyor. Puanlama objektifliği tam olarak sağlanamıyor..."

Yapılan analizlerin sonuçlarında öğrencilere yöneltilen soruların bilişsel düzeyinin 5. sınıftan 8. sınıfa doğru ilerledikçe üst düzey düşünme becerileri gerektiren soruların artığı görülmektedir.

\section{Sonuç ve Öneriler}

Bu çalışmada, ilköğretim kademeleri (ortaokul) 5., 6.,7. ve 8.sinıflarda görev yapan Fen Bilimleri öğretmenlerinin yazılı sınavlarda sordukları soruların Bloom Taksonomisi'nin bilişsel seviyelerine göre hangi seviyede olduklarını ve soru biçimleri analiz edilmiştir. Elde edilen veriler Bloom'un Bilişsel Alan Taksonomisine göre tasnif edilmiştir. Analizler neticesinde toplam soruların \%59,5'i bilgi, \%20,4' ü kavrama, \%13,4'ü uygulama, \%5,2'si analiz ve \%1,5'i sentez seviyesinde oldukları saptanmıştır.

Muhtelif zamanlarda ülkemizdeki farklı illerde ve okullarda yazılı sınav sorularının seviyelerini belirlemeye yönelik olarak yapılan çalışmalarda da benzer sonuçların alındığı görülmektedir. Bu çalışmadaki verilerin analizinden elde edilen bulgu ve yorumlara göre şu sonuçlara ulaşılmıştır. Fen Bilimleri öğretmenlerinin birçoğu öğrencilerinin seviyelerinin düşük olduğu ve dolayısıyla dersleri anlamakta güçlük çektikleri yönünde bir algıya sahip oldukları tespit edilmiştir. Bu algı nedeniyle derslerin yüzeysel bir şekilde işlendiği, fazla detaya inilemediği ve çoğunlukla yüzeysel ve basit örnek problemlerle derslerin geçiştirildiğini beyan etmişlerdir. Bu ön yargıların yanında, ders saatinin yetersiz olması, müfredatın çok yoğun olması, öğrencilerin hazır bulunuşluk düzeylerinin yetersizliği gibi sebepleri ileri süren öğretmenler sınavlarda düşük seviyeli sorular sormayı tercih ettikleri saptanmıştır.

Öğrencilere neden açık uçlu sorular sorulmadığı yöneltildiğinde ise öğrencinin yazma becerisinin olmamas1, soruları cevaplarken ifade etmek istediğini tam olarak ifade edememesi, öğrencilerin okunaklı yazamaması gibi çeşitli sebepler öne sürmektedirler. İlköğretim kademelerinde öğrenciler bu tür sorunları aşamazsa ve doğru olanı öğrenemezse daha sonraki yıllarda bunları düzeltmek zor veya imkânsız olacaktır. Öğretmenlerden beklenen ise, öğrencilerde bilimsel düşünmeyi ve sorgulamayı geliştirme gibi temel hedefi olan Fen Bilimleri dersinde öğrencileri düşünmeye sevk edecek, üst düzey düşünme becerilerini kullanmayı gerektirecek sorular yöneltmeleridir. Ayrıca öğretmenlere ölçme değerlendirme konusunda ve özellikle soru hazırlama konusunda hizmet içi eğitim verilmelidir. $\mathrm{Bu}$ hizmet içi eğitimlerde Bloom'un Bilişsel Alan Taksonomisi ve benzeri soru analiz ölçütleri kullanılmalı ve soru hazırlarken referans olarak bunlardan yararlanmaları tavsiye edilmelidir. Aynı okul ya da ilde çalışan öğretmenler ortak çalışmalar yaparak Bloom Taksonomisinin tüm bilişsel seviyelerine aynı oranda yer vermeleri sağlanarak öğrencilerin yaratıcı taraflarının ortaya çıkarılması sağlanmalıdır. Öğretmenlerin sınav sorularını sağlıklı bir şekilde değerlendirebilmesi için ölçme ve değerlendirme konusunda bilinçlendirilip ve bu alanda daha fazla çalışma yapmaları gerekmektedir.

\section{Kaynakça}

Akpınar, E. (2003). Ortaöğretim Coğrafya Dersleri Yazılı Sınav Sorularının Bilişsel Düzeyleri. Erzincan Eğitim Fakültesi Dergisi, 5(1), 13-21

Anıl, D., \& Acar, M. (2008). Sınıf Öğretmenlerinin Ölçme Değerlendirme Sürecinde Karsilastiklari Sorunlara İliskin Görüsleri. Yüzüncü Yll Üniversitesi Ĕ̈itim Fakültesi Dergisi, 5(2), 44-61. 
Baysen, E. (2006). Öğretmenlerin Sınıfta Sordukları Sorular ile Öğrencilerin $\mathrm{Bu}$ Sorulara Verdikleri Cevapların Düzeyleri. Kastamonu Eğitim Dergisi, (14)1, 21-28.

Birgin, O. (2016). Bloom Taksonomisi. İçinde: Matematik Eğitiminde Teoriler, (520-532). Ankara: Pegem Akademi.

Çakan, M. (2004). Öğretmenlerin Ölçme-Değerlendirme Uygulamaları ve Yeterlik Düzeyleri: İlk Ve Ortaöğretim. Ankara Üniversitesi Ĕ̆itim Bilimleri Fakültesi Dergisi, 37(2), 99-114.

Çınar, İ., \& Gürbüz, O. (2010). Yapılandırmacı Anlayış ve Çeşitleri. İçinde: Ĕ̌gitim Bir-SenEğitime Bakış, 6 (16) 56-60.

Dindar, H., \& Demir, M. (2006). Beşinci Sınıf Öğretmenlerinin Fen Bilgisi Dersi Sınav Sorularının Bloom Taksonomisine Göre Değerlendirilmesi. Gazi Ĕ̈itim Fakültesi Dergisi, 26(3), 87-96.

Dursun, A. (2014). YGS 2013 Matematik Sorularl ile Orta Ögretim 9. Sinıf Matematik Sinav Sorularının BloomTaksonomisi ve Öğretim Programına Göre Değerlendirilmesi. Yüksek Lisans Tezi, İstanbul: Aydın Üniversitesi-Yıldız Teknik Üniversitesi.

Gündüz, Y. (2009). İlköğretim 6, 7 ve 8. Sinıf Fen ve Teknoloji Sorularının Ölçme Araçlarına ve Bloom'unBilişsel Alan Taksonomisine göre Analizi. Yüzüncü Yll Üniversitesi Ĕ̌itim Fakültesi Dergisi, (6)2, 150-165.

Kaptan, F. (1998). Fen Bilgisi Öğretimi. Ankara: Anı Yayıncılik.

Koray, Ö., \& Yaman, S. (2002). Fen bilgisi öğretmenlerinin soru sorma becerilerinin Bloom Taksonomisine göre değerlendirilmesi. Gazi Üniversitesi Kastamonu Ĕgitim Dergisi, 10(2), 317-324.

Köğce, D., \& Baki, A. (2009). Farklı türdeki liselerin matematik sınavlarında sorulan soruların Bloom taksonomisine göre karşılaştırılması. Kastamonu Eğitim Dergisi, 17(2), 557-574.

Nagihan, T., \& Saraçoğlu, S. (2011). Fen Ve Teknoloji Dersi Yazılı Sorularının Yenilenmiş BloomTaksonomisi'ne Göre İncelenmesi. TÜBAV Bilim Dergisi, 4(4), 235-246.

Ocak, G. (2010). Yapılandırmacı öğrenme Uygulamalarına Yönelik Öğretmen Tutumları. Gazi Üniversitesi Gazi Eğitim Fakültesi Dergisi, (30), 835-857.

Yaşar, Ş. (1998). Yapısalcı Kuram ve Öğrenme-Öğretme Süreci. Anadolu Üniversitesi Ĕgitim Fakültesi Dergisi, 8(1-2), 68-75. 